\title{
Artefatos tecnológicos digitais interativos: Estratégias projetuais para fomento da mediação de conteúdo em museus
}

Content mediation and digital technology:

Visitors experiences in museums

\section{fauusp \\ mestrado}

\section{Diego Enéas Peres Ricca, Clice de Toledo Sanjar Mazzilli}

RICCA, D. E. P.

Graduado em Arquitetura e Urbanismo pela

Universidade de Fortaleza (2013) e Mestrando em Design FAU USP (2018). Bolsista CAPES e membro do LabVisual FAU USP. Tem experiência em projetos arquitetônicos especializados em entretenimento.

Graduated in Architecture and Urbanism from the University of Fortaleza (2013) and Master's degree in Design from FAU USP (2018), CAPES Fellow and member of LabVisual FAU USP. Has experience in architectural projects specialized in entertainment.

MAZZILLI, C. T. $\mathbf{S}$. Professora Associada nos cursos de Arquitetura e Urbanismo e Design da Universidade de São Paulo. Orienta pesquisas em design gráfico e ambiental com ênfase em: narrativas visuais; design do livro; processos experimentais em design; espaços infantis; Associate Professor of Architecture and Urbanism and Design at the University of São Paulo. Her research interests include both graphic and environmental design with emphasis on: visual narratives; book design; experimental design processes; children's spaces.

\section{contato}

diego.ricca.pagmail.com cliceluusp.br

\section{lattes}

http://lattes.cnpq.br/ 8251503092812059
Hoje a tecnologia digital se aplica de forma maior e mais variada em diversos aspectos do cotidiano. Com esteio nisso objetiva-se identificar aspectos projetuais relevantes no sentido da mediação de conteúdo e potencialização do aprendizado de visitantes em museus por meio da interação com artefatos tecnológicos digitais. Primeiramente realizou-se um estudo de reconhecimento de estratégias projetuais relevantes aplicadas em 21 exemplos visitados, pelo qual foi obtida uma visão geral do estado da arte de aplicações, nacionais e internacionais, ensejando a identificação de estratégias projetuais de cunho estrutural e conceitual. Em seguida, tais análises foram articuladas a um aprofundamento na observação do usuário em interação, por meio de dois estudos de caso selecionados dentre os projetos anteriormente elencados. 0 primeiro foi o projeto A Voz da Arte, fruto da parceria entre Pinacoteca de São Paulo e a IBM. Já o segundo se concentra na instalação Relevos da Terra em 3D, situada no Museu Catavento Cultural. A coleta de dados se deu por levantamento de áudio e vídeo da interação de 15 visitantes no primeiro, e 12 no segundo artefato, seguida por entrevistas semiestruturadas, tratando de questões relativas às experiências individuais da atividade. Por fim realizou-se uma categorização dos pontos relevantes observados, produzindo um diagrama que sintetiza as estratégias projetuais elencadas em três dimensões de estímulos da interação: materiais; racionais e emocionais.

Palavras-chave: Design de interação; Mediação; Tecnologia em museus; Teoria da atividade
Today digital technology is applied in a larger and more varied way in different aspects of daily life. Based on this, this research aims to identify relevant design aspects in what concerns content mediation and enhancement of the visitor's learning in museums through interaction with digital technological artifacts. First, a recognition study was carried out applied on 21 examples visited, which provided an overview of the state of the art of national and international applications, leading to the identification of conceptual and structural strategies. Such analyses were articulated to a deepening in the observation of the user in interaction, through two case studies selected among the projects previously listed. The first was the A Voz da Arte project, the result of the partnership between Pinacoteca de São Paulo and IBM. The second one focuses on the Relevos da Terra em 3D installation, located in the Catavento Cultural Science Museum. The data collection was done by audio and video survey of the interaction of 15 visitors in the first, and 12 in the second artifact, followed by semistructured interviews, dealing with issues related to the individual experiences of the activity. Finally, a categorization of the relevant points observed was carried out, producing a diagram that synthesizes the projected strategies in three dimensions of stimuli of the interaction: material; rational and emotional.

Keywords: Interaction design; Mediation; Technology in museums; Activity theory realização

ppgdesign_fauusp
5 dezembro 2018

cidade universitária, são paulo, sp 